\title{
The poisoning of rhinos and tigers in Nepal
}

\author{
Esmond Bradley Martin
}

\begin{abstract}
Although it is a poor country, Nepal has been responsible for one of the greatest rhino conservation success stories. In 1968 its population of greater one-horned rhinoceros Rhinoceros unicornis was estimated at 81-108 individuals; by 1990 the population had increased to 400, a tremendous achievement for a country with very limited financial resources. However, in 1990 the government collapsed and the enforcement of law and order was not very effective. Rhinos were poached for their horns and tigers for their bones. Poachers started poisoning rhinos, apparently copying the methods used previously for killing nuisance tigers. The author, who visited Nepal in 1991, reports on these new threats and discusses what needs to be done to remedy the situation.
\end{abstract}

The rhinoceros is of very great religious and cultural significance in Nepal. Each Head of State must perform a religious ceremony at least once in his life, in which he must kill a rhino and offer its blood to his ancestors. Ordinary Nepalese also sometimes perform a similar ceremony using rhino skin. The rhino is so revered religiously and culturally that every part of the rhino is eaten or used in some way when opportunities arise (Martin, 1985).

\section{Rhino protection and poaching}

Since the early 1970s the Nepalese government has allocated a considerable amount of money and human resources for the protection of the rhino. In 1975200 armed Royal Nepalese Army personnel were permanently stationed inside Chitwan National Park, which then contained the country's only rhino population. By 1982 this force had increased to 500 personnel, supplemented by more than 100 armed members of the Gaidi Gasti (the Forest Department's rhino guards) who were stationed on the outskirts of the park to prevent rhinos being killed when they strayed outside its boundaries to eat crops. As a result of this large anti-poaching force, together with the efforts of the regular park staff, and due to strong support from the King, there was no evidence of poaching between 1977-1983.

Despite the continued protection, however, 21 rhinos were poached in and around Chitwan between 1984 and 1990. One cause was probably the rising price of rhino horn on the world market, coupled with the fact that the people organizing the poaching developed stronger and more sophisticated connections with traders in India. The biggest problem, however, has been the political upheaval, which started in early 1990 and resulted in the replacement of the government and a reduction in the King's power. The police, the army and the law in general lost influence and some criminals took advantage of this situation and turned their attentions to rhinos and their valuable horn.

The first incident of this particular wave of poaching occurred on the night of 26 January in Patan's Central Zoo near Katmandu. A 15year-old female rhino and a 6-year-old male were killed with rat poison, containing zincphosphide. The animals presumably took several hours to die and the poachers had time only to remove the horn from the male before escaping.

Between 10 May and 31 July 1990 five more rhinos were killed in and around Chitwan. All but one were killed during the monsoons, when many government employees traditionally take leave and when patrols are hampered by flooded roads. The rhinos are also at 
greater risk at this time because they frequently leave the park to feed on crops. On 10 May a male rhino was found dead with its horn removed, $14 \mathrm{~km}$ from Tiger Tops Jungle Lodge in western Chitwan. The cause of death was probably insecticide-laced vegetables on the outskirts of the park. On 8 June another animal was found shot, minus the horn, in the middle of the park, and on 7 July a third was found, also without its horn, just outside the park, but the cause of death was not established. The fourth rhino was found on 28 July outside the north-east corner of the park by guards, who also discovered the cause of death-a pumpkin filled with liquid insecticide. On 31 July, near to where this animal had been poisoned, a fifth rhino wandered on to a farm and was killed by a villager with a spear; no attempt was made to remove the horn.

Poachers are only occasionally captured. Four of the poachers who killed the fourth rhino were arrested by the Gaidi Gasti in August 1990 after extensive detective work and the horn was recovered from a pit next to the house of one of the poachers. Reportedly there were six men involved but the two others have not been caught.

Although other parts of the rhino are valuable, poachers only remove the horn, perhaps because of lack of time. They sell the horn to middlemen, who in 1989 were paying the equivalent of $\$ U S 8000-10,000$ per $\mathrm{kg}$. This is a huge sum compared with local wages for unskilled work; even a game scout is paid less than the equivalent of $\$ U S 400$ a year. Businessmen who buy the horn live in Narayangadh and Tadi bazaar, both close to Chitwan. The horn is smuggled out of Nepal, usually via India to Taiwan, where in 1989-1990 traders were paying just over the equivalent of $\$ U S 20,000 \mathrm{a} \mathrm{kg}$.

Apart from the breakdown in law and order, there have been difficulties in carrying out anti-poaching activities. Although in 1990 700 army personnel were stationed at 30 posts in the park, a senior army officer complained to me about shortages of transport and radios, as well as a breakdown in the intelligencegathering system. Information about potential poachers was no longer reaching the army and officers claimed that it was not their responsibility to leave the park to collect it, but rather that of the park authorities and the Gaidi Gasti. Army personnel have rather poor relations with villagers because they are sometimes arrogant, especially when they arrest local people for illegal tree-felling and livestock-grazing. The Gaidi Gasti unit is also struggling to carry out its patrol work. Their official force of 185 men was reduced to 124 by January 1991 because all recruitment was halted in mid-1990. Patrol work is limited by a shortage of vehicles and a lack of domesticated elephants and the unit also does not have an intelligence-gathering system.

Chitwan's own guard unit is also undermanned, numbering only 45 in January 1991, with only 35 on duty on any one day. This is one-third of the number required (T. R. Adhikari, pers. comm.). None of the park staff is armed so they can do little if they encounter armed poachers. Their role now is mainly administrative and because they no longer have an intelligence-gathering system their effectiveness is reduced. Several wellinformed people not working for the government confirmed my own impressions that illegal activities had increased in the park since my previous visits in 1982 and 1986.

One of the greatest problems for anti-poaching operations is that there is no longer adequate funding for the intelligence-gathering networks, which used to be very effective against poaching in Chitwan. The government severed funds to the park in 1988 because the staff were unable to conform to the very complicated official payment system. Some members of the Parks Department are concerned that, while 85 per cent of its total budget (Rs139,931,000, about \$US4,600,000 for the fiscal year 1990/91) is allocated to the army to patrol national parks and wildlife reserves, rhino poaching is, nevertheless, accelerating.

\section{Tigers}

Rhinos are not the only valuable and endangered species being killed. There are about 170 
Bengal tigers Panthera tigris in Chitwan National Park and adjacent areas to the east and south, extending into a small part of India. This is about one-half of Nepal's total tiger population (C. McDougal, pers. comm.) In western Chitwan, in 1989, McDougal discovered the remains of a poisoned tigress, with two poisoned mongooses nearby. Two adult male tigers disappeared in the same locality within a day of each other, and two more tigresses with six cubs also perished in that year. In 199014 tigers (six adults and eight cubs) vanished, also in the western part of the park. McDougal believes that at least 12 of these 25 tigers were poisoned and further casualties probably lie undetected in the dense vegetation in less visited areas of the park. National Parks officials agree that tiger poaching has increased in Nepal. According to the Assistant Warden of Chitwan (T. R. Adhikari)

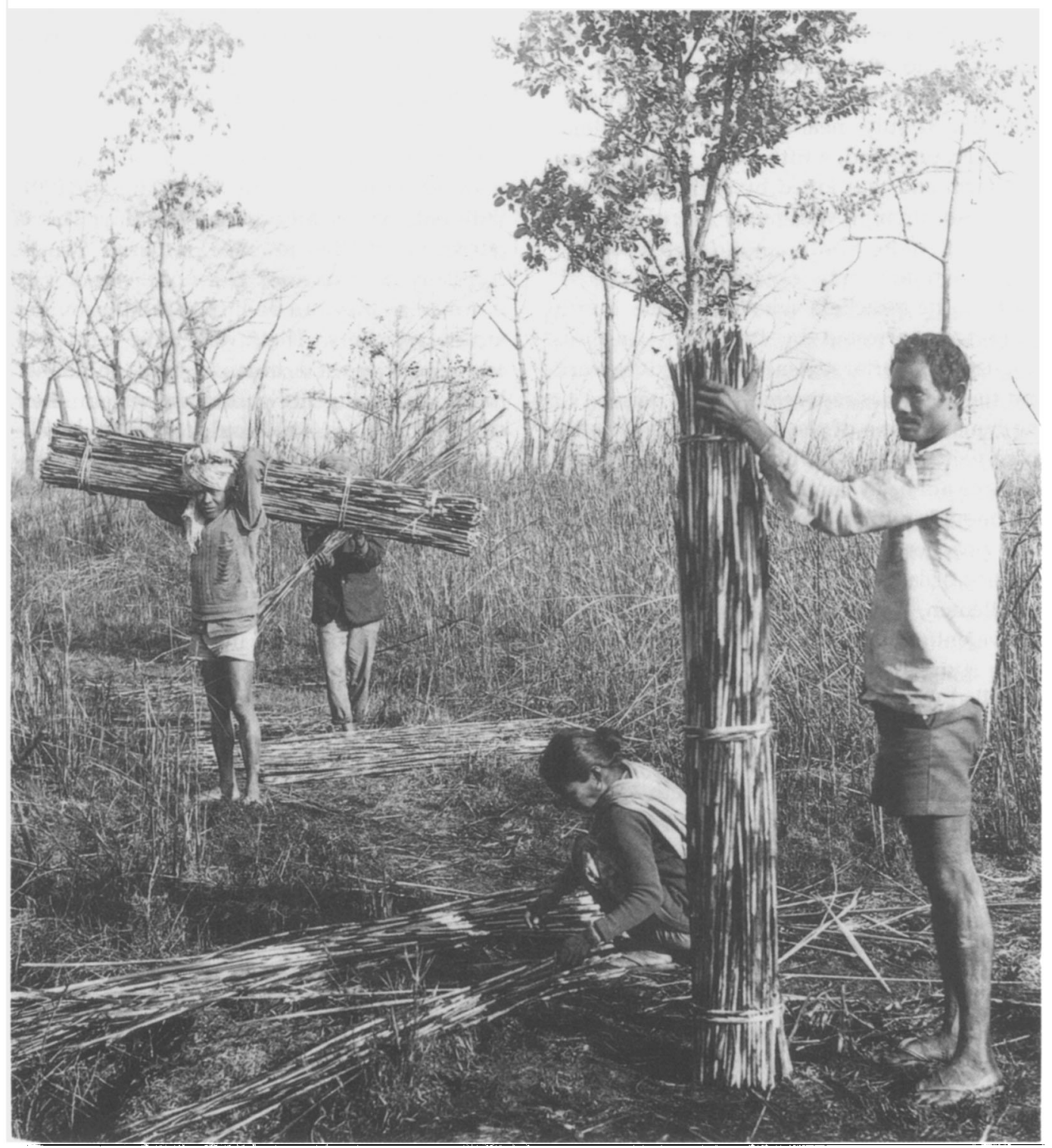

Once a year villagers are allowed to cut grass and reeds in Chitwan National Park (Esmond Bradley Martin). 
at least 10 per cent of the park's tiger population was poisoned in 1988-1989.

Historically villagers have killed tigers on the edge of the park because of livestock losses. Carcasses of cattle or water buffalo killed by tigers were laced with poison so that when the tiger returned to feed it was poisoned. In 1989, however, poachers started to kill tigers for economic gain using the same method, but buying old cattle from farmers for use as bait. Most of the tiger poaching occurs on the east side of the park and in the adjacent Parsa Wildlife Reserve (C. McDougal, pers. comm.).

In January 1991 five poachers who had just been caught said that they had killed three tigers, one inside and two outside the park, by lacing cattle carcasses with poison. The men, most of them poor local farmers, were promised the equivalent of \$US130 a $\mathrm{kg}$ for the bones, the only product of economic importance to the local traders. The tiger bones are usually sent via Tibet to China, where there is a major traditional medicine market for them, mostly for remedies to relieve rheumatic pain. Park officials reported that 20 sacks of tiger bones were confiscated at a post office in north-west Nepal near the Tibet border in 1988. There is also some evidence that tiger bones from India pass through Nepal to Tibet.

\section{The future}

\section{Funding}

The recent upsurge in rhino and tiger poaching in Nepal needs addressing urgently. The most important and simplest step would be to re-establish the intelligence-gathering network by allocating enough money to pay informants for reliable information about poachers and traders. In 1973, when rhino poaching was once before serious in Chitwan, the FFPS Oryx $100 \%$ Fund donated $£ 250$ to anti-poaching work; this relatively small amount of money was responsible, in 3 months, for the apprehension of 17 illegal hunters and the end of the problem at the time. In January 1991, in order to help combat the increase in tiger poaching, the UK-based International Trust for Nature Conservation gave the equivalent of \$US67 to pay four local men to collect information on suspects. That same month evidence from these informants led to the arrest of the five poachers mentioned earlier. This illustrates what excellent results can be achieved at a relatively low cost. Re-establishment and operation of the intelligence system would cost \$US3000 over a 3-year period, an insignificant amount compared with the export value of a breeding pair of rhinos, which is about $\$$ US 250,000 .

\section{Legal action}

Fines and prison sentences for poaching offences should be increased significantly and maximum publicity should be given to poaching-related convictions to deter other wouldbe poachers.

\section{Park management}

The Forest Department's Gaidi Gasti unit outside the park and the army within it must improve their patrolling. In order to do this they require modern equipment, vehicles and trained elephants, particularly in the monsoon

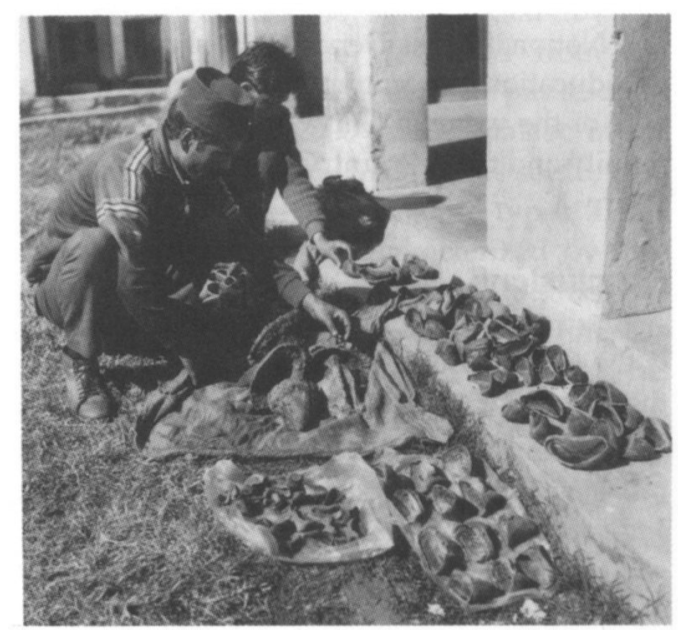

Two members of the Forest Department in Nepal with rhino horns and nails collected from carcasses found in Chitwan National Park (Esmond Bradley Martin). 
period when the majority of rhinos are killed. Perhaps the tourist lodges, closed during the rains, could lend their trained elephants to the army. The staff need better training and there must be more co-operation between all the units concerned with anti-poaching activities.

\section{Local people}

The negative attitude of people living on Chitwan's borders should be tackled. The thousands of destitute villagers living near the park receive very little economic benefit from Chitwan, and they are prevented from grazing their livestock there. Foreign tourists visit in ever greater numbers - 36,072 in 1990 compared with 836 in 1974 - but the additional employment opportunities are not sufficient to satisfy the demand from the large number of villagers. One benefit villagers do receive is the right to cut as much grass and reeds as they wish for thatching during 15 days each January for a fee of Rs5 (approximately $\$$ US0.17). A major expense borne by villagers, however, is crop damage by rhinos. Park staff must attempt to reduce this devastation, perhaps by using a simple electric fence in the worst affected areas.

\section{Education}

The National Parks Department should set up an education programme to promote awareness of the value of Chitwan to the local community and to the country as a whole.

\section{Conclusions}

If the Chitwan National Park is to survive in the long term, the local villagers must share in the economic benefits from the park. The government authorities should endeavour to develop policies that protect Chitwan's wildlife and simultaneously improve the wellbeing of the human population that surrounds the park. Without improved co-operation between the authorities and villagers, poaching will inevitably continue to threaten two of Indo-Malaya's most endangered species.

\section{Postscript}

Another rhino was speared to death within Chitwan in May 1991 (T. M. Maskey, pers. comm.).

\section{Acknowledgments}

I wish to thank WWF-International for the financial support that made it possible for me to carry our this research in Nepal. Dr T. M. Maskey, Dr Charles McDougal and Mr Biswa Upreti, Director General of the Department of National Parks and Wildlife Conservation, read my manuscript and made valuable comments. Biswa Upreti and Dr Hemanta Mishra helped to organize my travel in Nepal. Dr Maskey very kindly drove me to Chitwan National Park and accompanied me in my work, In addition, I am most grateful to Tika Ram Adhikari, Lisa Choegyal, Elizabeth Hawley and Gam Bahadur Tamang for assisting me with my work.

\section{Reference}

Martin, E. B. 1985. Religion, royalty and rhino conservation in Nepal. Ory $x, 19,11-16$

Esmond Bradley Martin, PO Box 15510, Mbagathi, Nairobi, Kenya. 